\title{
EFEKTIVITAS PELATIHAN PIJAT TUINA TERHADAP PENGETAHUAN IBU BALITA DI DUSUN SETAN DESA MAGUWOHARJO, KELURAHAN DEPOK, KABUPATEN SLEMAN
}

\author{
Ester Ratnaningsih ${ }^{1}$, Harliana Riska ${ }^{2}$, Inez Faradila Azmy ${ }^{3)}$ \\ 1.Prodi Kebidanan Program Profesi Universitas Respati Yogyakarta \\ 2.Prodi Kebidanan Program Profesi Universitas Respati Yogyakarta \\ ${ }^{3}$ Mahasiswa Prodi Pendidikan Profesi Bidan Universitas Respati Yogyakarta \\ Email: esteratna@respati.ac.id
}

\begin{abstract}
ABSTRAK
Masa balita merupakan golden period atau masa keemasan proses tumbuh kembang yang berlangsung sangat pesat. Periode ini dapat diwujudkan apabila anak memperoleh asupan gizi yang optimal. Upaya untuk mengatasi kesulitan makan pada balita dapat dilakukan dengan cara non farmakologi melalui pijat tui na. Tujuan penelitian ini adalah melihat pengaruh efektifitas pelatihan pijat tuina terhadap pengetahuan ibu balita. Metode penelitian ini adalah pre-eksperiment dengan desain one group pre test post test design. Pengambilan sample dengan teknik incidental sampling sehingga di dapatkan 23 ibu balita di Dusun Setan di Desa Maguwoharjo, Kelurahan Depok, Kabupaten Sleman. Instrument untuk mengukur pengetahuan ibu balita dalam penelitian ini merupakan kuesioner. Data yang terkumpul dianalisis dengan uji Paired sample $t$ test. Hasil penelitian menunjukkan adanya pengaruh pengetahuan ibu sebelum dan sesudah pelatihan. Sebelum pelatihan persentase pengetahuan dalam kategori kurang (97\%), sedangkan setelah pelatihan persentase pengetahuan meningkat menjadi baik (22\%) dan cukup (48\%). Kesimpulan hasil uji statistik adalah ada pengaruh pelatihan pijat tuina terhadap pengetahuan ibu melakukan pijat tuina dengan nilai signifikan $0.000<0,05$. Dengan demikian bahwa pelatihan pijat tuina mampu meningkatkan pengetahuan ibu balita.
\end{abstract}

Kata Kunci : Pelatihan Pijat Tui na, Pengetahuan Ibu

\section{ABSTRACT}

Toddlerhood is the golden period of the growth and development process that takes place very rapidly. This period can be realized if the child gets optimal nutritional intake. Efforts to overcome eating difficulties among under-five children can be performed in a non-pharmacological method through tuina massage. This study aims to observe the effectiveness of tuina massage training on knowledge among mothers with under-fivechildren. This was a pre-experiment study with a one group pre-test post-test design. Sampling was performed using incidental sampling technique so that 23 mothers with under-five childrenatSetan Hamlet, Maguwoharjo Village, DepokSub-District, SlemanDistrict were obtained. A questionnairewasused as the study instrument to measure the knowledge of mothers with under-five children involved. The data collected were analyzed using the Paired sample t test. The results showed that there was a difference in mother's knowledge before and after the training. The percentage of knowledge before training was in the poorcategory (97\%), while the percentage of knowledge after training increased to good category (22\%) and moderatecategory (48\%). Based on the statistical test results, it can be concluded that there was an effect of tuina massage training on mother's knowledge to performtuina massage with a significant value of $0.000<0.05$. Thus, tuina massage training was effective to increase the knowledge of mothers with under-five children.

Keywords: TuiNa Massage Training, Mother's Knowledge

\section{PENDAHULUAN}

Masa balita merupakan periode penting dalam proses tumbuh kembang seorang anak, karena termasuk golden period atau masa keemasan proses tumbuh kembang yang berlangsung sangat pesat. Istilah tumbuh kembang sebenarnya mencakup dua peristiwa yang berbeda tetapi saling berkaitan dan sulit dipisahkan. Pertumbuhan (growth) mengacu pada perubahan fisik tertentu dan peningkatan 
ukuran tubuh anak, semua bentuk pertumbuhan anak ini dapat diukur secara langsung dan dapat dipercaya hasilnya. Sedangkan perkembangan (development) mengacu pada bertambahnya kemampuan (skill) dalam struktur dan fungsi tubuh yang lebih kompleks dalam pola yang teratur dan dapat diramalkan sebagai hasil dari proses pematangan organ atau individu. (Marimbi, 2010)

Periode emas dapat diwujudkan apabila memperoleh asupan gizi yang sesuai untuk tumbuh kembang secara optimal. Setelah melewati usia 1 tahun anak akan mulai pilih-pilih makanan dan kemampuannya untuk menolak makanan yang diberikan kepadanya. Penolakan itu tentu tidak boleh dijadikan alasan oleh kedua orang tuanya untuk melakukan pemaksaan karena mempertahankan diri anak. Jika gejala tidak mau makan dibiarkan berlangsung maka pertumbuhan tubuhnya menjadi pelan dan perkembangan berat badannya cenderung turun, padahal pada usia dini seperti ini pertumbuhan balita harus tetap berjalan dan gizi tetap diperlukan (Adiningsih, S. 2010).

Berdasarkan hasil Riskedas Tahun 2018 menunjukkan bahwa Indonesia masih memiliki masalah kekurangan gizi kurang dari 13,9 pada tahun 2013, menurun menjadi 13,8 pada tahun 2018. Sedangkan gizi buruk dari 5,7 pada tahun 2013 menurun cukup signifikan menjadi 3,9 pada tahun 2018 (Kemenkes RI, 2019). Fenomena sulit makan pada balita sering menjadi masalah bagi orang tua atau pengasuh balita. Faktor kesulitan makan inilah yang sering dialami oleh usia balita.( Mascola, 2010)

Sebagian besar kesulitan makan pada bayi berkaitan dengan gangguan pertumbuhan, sedangkan kesulitan makan pada anak disertai dengan gangguan perkembangan. Kesulitan makan pada anak yang tidak segera ditangani dapat menyebabkan malnutrisi, dehidrasi, berat badan kurang, ketidakseimbangan elektrolit, gangguan perkembangan kognitif, gangguan kecemasan, dan pada keadaan yang lebih parah dapat menjadi kondisi yang mengancam hidup (Antolis., 2012). Upaya untuk mengatasi kesulitan makan pada balita dapat dilakukan dengan cara farmakologi dan non farmakologi. Upaya farmakologi dapat dilakukan dengan pemberian vitamin (Soedjatmoko, 2011).
Sedangkan non farmakologi antara lain melalui minuman herbal atau jamu, pijat, akupresur, dan akupunktur (Ferry Wong 2011). Saat ini kebanyakan orang tua mengatasi kesulitan makan anak sebatas pemberian multivitamin tanpa memperhatikan penyebabnya. Dewasa ini telah dipopulerkan kembali dari tehnik pijat bayi, yakni pijat Tui Na. Pijat ini dilakukan dengan tehnik pemijatan meluncur (Effleurage atau Tui), memijat (Petrissage atau Nie), mengetuk (Tapotement atau Da), gesekan, menarik, memutar, menggoyang, dan menggetarkan titik tertentu sehingga akan mempengaruhi aliran energi tubuh dengan memegang dan menekan tubuh pada bagian tubuh tertentu. Pijat Tui Na ini merupakan tehnik pijat yang lebih spesifik untuk mengatasi kesulitan makan pada balita dengan cara memperlancar peredaran darah pada limpa dan pencernaan, melalui modifikasi dari akupunktur tanpa jarum, teknik ini menggunakan penekanan pada titik meridian tubuh atau garis aliran energi sehingga relatif lebih mudah dilakukan dibandingkan akupuntur (Sukanta, P. , 2010)

Hasil penelitian Annif Munjidah (2015) yang berjudul efektifitas pijat Tui $N a$ dalam mengatasi kesulitan makan pada balita di RW 02 kelurahan Wonokromo Surabaya bulan Agustus 2015 menyebutkan bahwa pijat Tui $\mathrm{Na}$ berpengaruh positif terhadap kesulitan makan pada balita (Annif, 2015). Hasil penelitian hen Huan Liu dan Li ting Cen di Guangzhou tahun 2009 menyebutkan Pijat Tui $\mathrm{Na}$ berpengaruh positif terhadap perkembangan syaraf dan peredaran darah pada balita (Ekstein S , 2010). Berdasarkan dari latar belakang masalah yang telah penulis uraikan, maka penulis menerapkan asuhan inovasi pijat Tui $\mathrm{Na}$ untuk membantu meningkatkan nafsu makan pada balita yang diharapkan membantu ibu dalam mengatasi masalah nafsu makan pada balita.

$$
\text { Berdasarkan hasil Pelaksanaan }
$$

Program Indonesia Sehat Pendekatan Keluarga $(P I S-P K)$ Dusun Setan di Desa Maguwoharjo, Kelurahan Depok, Kabupaten Sleman tahun 2019 menunjukkan bahwa cakupan balita yang mendapat pemantauan perkembangan sebanyak $98 \%$ dari total 60 balita. Studi Pendahuluan di Dusun Setan di Desa Maguwoharjo, Kelurahan Depok, Kabupaten Sleman, pada bulan September 2019, pada 
penimbangan kegiatan posyandu kenaikan berat badan balita yang ditimbang hanya sekitar $70 \%$ yang mengalami kenaikan berat badan, $30 \%$ berat badannya tetap. Masalah yang dihadapi ibu adalah kesulitan makan pada anaknya. Pelatihan Pijat Tui na merupakan cara untuk meningkatkan pengetahuan dan ketrampilan masyarakat khususnya ibu balita untuk mengatasi kesulitan makan pada balita, Sehingga harapannya dengan di pijat tui na nafsu makan anak meningkat.

\section{METODE}

Metode penelitian yang dipakai dalam penelitian ini adalah pre-eksperiment dengan desain one group pre test post test design. Pengambilan data penelitian ini dilakukan pada tanggal 22 Desember 2019, kegiatan berupa pelatihan pijat tuina pada ibu yang memiliki balita di Dusun Setan, Desa Maguwoharjo, Depok, Sleman. Populasi dalam penelitian ini ialah ibu yang memiliki balita di Dusun Setan, Desa Maguwoharjo, Depok, Sleman. Teknik sampling yang digunakan dalam penelitian ini adalah incidental sampling, di dapatkan sebanyak 23 orang ibu balita. Instrument untuk mengukur pengetahuan responsen dalam penelitian ini adalah kuesioner.

Pengisian instrument ini dilakukan sebanyak 2 kali yakni sebelum diberikan pelatihan (pre-test) dan setelah diberikan pelatihan (post-test). Analisis data mengenai karakteristik ibu balita di analisis menggunakan distribusi frekuensi. Adapun variabel pengetahuan di analisis menggunakan dianalisis dengan menggunakan uji $t$ dependen/paired sample t test. Taraf kesalahan di tetapkan 5\% atau taraf kepercayaan $95 \%$.

\section{HASIL}

\section{Karakteristik Responden}

Responden yang terlibat di dalam penelitian ini merupakan ibu Balita usia 1-5 tahun sebanyak 23 orang. Ibu Balita di Dukuh Setan, Desa Maguwoharjo, Kecamatan Depok, Kabupaten Sleman yang menjadi responden penelitian ini memiliki berbagai karakteristik. Tabel 1 menunjukkan sebaran responden berdasarkan karakteristik umur ibu, pendidikan terakhir, suku bangsa, pekerjaan dan penghasilan ibu.

\section{Tabel 1. Distribusi Frekuensi dan Persentase Data Demografi Responden}

\begin{tabular}{|c|c|c|}
\hline Data Demografi & $\mathbf{N}$ & Persentase \\
\hline \multicolumn{3}{|l|}{ Umur } \\
\hline$<20$ tahun & 2 & $8,7 \%$ \\
\hline 20-25 tahun & 4 & $17,4 \%$ \\
\hline $26-30$ tahun & 10 & $43,5 \%$ \\
\hline $31-35$ tahun & 4 & $17,4 \%$ \\
\hline$>35$ tahun & 3 & $13,0 \%$ \\
\hline \multicolumn{3}{|l|}{ Tingkat Pendidikan } \\
\hline Rendah (SD, SMP) & 7 & $30,5 \%$ \\
\hline Menengah (SMA) & 13 & $56,5 \%$ \\
\hline Tinggi (Perguruan & 3 & $13,0 \%$ \\
\hline \multicolumn{3}{|l|}{ Tinggi) } \\
\hline \multicolumn{3}{|l|}{ Status Pekerjaan Ibu } \\
\hline Bekerja & 20 & $87,0 \%$ \\
\hline Tidak Bekerja & 3 & $13,0 \%$ \\
\hline \multicolumn{3}{|l|}{ Suku Bangsa } \\
\hline Jawa & 21 & $91,3 \%$ \\
\hline Sunda & 2 & $8,7 \%$ \\
\hline \multicolumn{3}{|c|}{ Penghasilan Ibu per bulan } \\
\hline$<\mathrm{UMR}$ & 19 & $82,6 \%$ \\
\hline$\geq \mathrm{UMR}$ & 4 & $17,4 \%$ \\
\hline $\begin{array}{l}\text { Berdasarkan ke } \\
\text { umur ibu dengan us } \\
\text { kelompok umur terl } \\
10 \text { orang }(43,5 \%)\end{array}$ & & $\begin{array}{l}\text { responden. Berdasarkan tingkat pendidikan, } \\
\text { maka terbanyak adalah pendidikan terakhir } \\
\text { menengah (SMA), yaitu } 13 \text { orang }(56,5 \%) \text {. } \\
\text { Berdasarkan status pekerjaan, ibu tidak bekerja }\end{array}$ \\
\hline
\end{tabular}


atau sebagai ibu rumah tangga adalah yang terbanyak, yaitu 20 orang (87 \%). Berdasarkan suku bangsa terbanyak adalah suku Jawa yaitu 21 orang (91,3\%). Berdasarkan penghasilan ibu per bulan dari total 32 ibu hanya 19 $(17,4 \%)$ yang memiliki penghasilan $\geq$ UMR

\section{Tabel 2. Tingkat Pengetahuan Responden Sebelum dan Sesudah Pelatihan Pijat} Tuina (n=23)

\begin{tabular}{lllll}
\hline \multicolumn{1}{r}{ Tingkat pengetahuan } & \multicolumn{3}{c}{ Pre test } & \multicolumn{2}{c}{ Post test $\mathrm{n}(\%)$} \\
\cline { 2 - 5 } & $\mathrm{n}$ & $\%$ & 5 & $\%$ \\
\hline Baik & 0 & & 11 & $48 \%$ \\
Cukup & 1 & $4 \%$ & 11 & $30 \%$ \\
Kurang & 22 & $97 \%$ & 7 & $30 \%$ \\
\hline
\end{tabular}

Berdasarkan data diatas, hasil pre-test menunjukkan bahwa pengetahuan pijat tuina yang dilakukan responden sebelum diberikan pelatihan tentang pijat tuina berada pada kategori cukup yakni sebanyak 1 orang $(4 \%)$, dan 22 orang $(97 \%)$ pada kategori kurang. Sementara itu setelah dilakukan pelatihan tentang pijat tuina, hasil post-test didapatkan dengan hasil yang lebih baik dimana terdapat 5 orang $(22 \%)$ responden yang dalam kategori baik, 11 orang $(48 \%)$ responden yang cukup dan 7 orang $(30 \%)$ responden dalam kategori kurang. Hal ini menunjukkan bahwa setelah dilakukan pelatihan tentang pijat tuina

\section{Tabel 3. Hasil Uji Hipotesis (Uji t)}

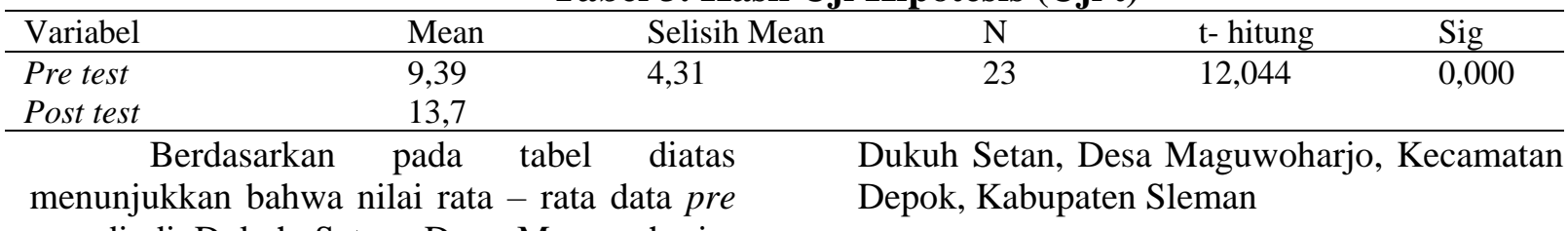

test di di Dukuh Setan, Desa Maguwoharjo, Kecamatan Depok pada 23 responden sebesar 9,39 dan rata-rata data post test sebesar 13,7. Rata - rata data post test di Dukuh Setan, Desa Maguwoharjo, Kecamatan Depok diberikan pelatihan tentang pijat tuina lebih baik dibanding dengan rata - rata data pre test sebelum diberikan pelatihan pijat tuina keduanya memiliki selisih 4,31 . Peningkatan rerata adalah signifikan/bermakna.

Nilai t yang diperoleh dari hasil uji $\mathrm{t}$ pre test dan post test sebesar 12,044 dengan nilai signifikan sebesar 0,000 . Hal ini menunjukkan nilai signifikansi lebih kecil dari $0,05(0,000<0,05)$, dan $t$ hitung lebih besar dari t tabel $(12,044>2,035)$ sehingga hipotesis dalam penelitian ini diterima. Hal ini menunjukkan bahwa ada pengaruh pelatihan pijat tuina terhadap pengetahuan ibu dalam melakukan pijat tuina pada anak balita di

\section{PEMBAHASAN}

Berdasarkan hasil yang diperoleh, maka pembahasan ini dilakukan untuk menjawab tujuan penelitian sebagai berikut:

\section{Karakteristik Demografi Responden}

Responden penelitian ini adalah ibu yang memiliki balita di Desa Setan, Desa Maguwoharjo, Kecamatan Depok, Kabupaten Sleman, Daerah Istimewa Yogyakarta. Jumlah responden 23 orang ibu. Berdasarkan Tabel 1 dapat diketahui bahwa sebagian besar responden berumur 26-30 tahun dengan proporsi 43,5 \%. Menurut teori Durkin (1995) usia 26-35 tahun termasuk kategori dewasa awal , dimana pada usia ini seseorang sudah dapat menentukan suatu pilihan dan dapat menyelsaikan masalah- masalah dalam kehidupan mereka. Umur sangat berhubungan dengan peningkatan kemampuan memperoleh 
pengetahuan, dimana pengetahuan yang dimiliki oleh ibu merupakan dasar dari tindakan ibu dalam upaya perawatan anak dalam menaikkan berat badannya.

Faktor yang berpengaruh dalam tingkat pengetahuan seseorang antara lain, tingkat pendidikan, sumber informasi, budaya, pengalaman, dan sosial ekonomi. (Wawan A. dan Dewi M.: 2011).Pengetahuan ibu balita dalam pijat tuina masih kurang jadi perlu adanya tindakan untuk upaya peningkatan pengetahuan ibu balita .

Rata-rata pendidikan responden yaitu SMA sebesar $56,5 \%$, pendidikan merupakan salah satu faktor yang mempengaruhi pengetahuan, pendidikan yang telah ditempuh oleh seseorang maka akan mempengaruhi pengetahuan mereka. Menurut Notoatmodjo (2012) menjelaskan bahwa pendidikan akan berdampak pada tingkat pengetahuan seseorang. Seseorang yang memiliki pendidikan tinggi akan mempunyai wawasan yang lebih luas dibandingkan dengan seseorang yang berpendidikan lebih rendah. Semakin tinggi tingkat pendidikan orang tua maka semakin tinggi pula pengetahuan dan pengalamannya dalam merawat anaknya khusunya dalam praktik pemberian makannya.

Berdasarkan status pekerjaan, responden pada penelitian ini bekerja sebesar $87 \%$, sedangkan ibu yang tidak bekerja sebanyak $23 \%$. Hasil penelitian ini sesuai dengan penelitian yang dilakukan oleh Suci Rahmawati, dkk (2018) dimana 100\% responden penelitiannya adalah ibu berkerja. Status pekerjaan ibu dapat mempengaruhi perilaku makan pada anak.Terdapat perbedaan pembentukkan kebiasaan makan bagi anakanak apabila ibu mereka sebagai ibu rumah tangga dan juga sebagai pencari nafkah.

\section{Pengetahuan Ibu Balita dalam Melakukan Pijat Tuina Sebelum dan sesudah dilakukan Pelatihan Pijat Tuina}

Skala penilaian pengetahuan dibedakan menjadi 3 kategori yaitu baik, cukup dan kurang. Hasil jawaban responden terhadap kuesioner pengetahuan ibu melakukan pijat tuina sebelum diberikan pelatihan (pre-test) yaitu 23 responden yang menjadi sampel hasil pretest menunjukkan bahwa sebagian besar pengetahuan pijat tuina pada ibu balita di Dukuh Setan, Desa Maguwoharjo, Kecamatan
Depok dalam kategori kurang sebesar 22 responden $(97 \%)$. Hal ini disebabkan karena selama ini pelaksanaan pijat pada bayi dan balita di masyarakat masih dipegang peranannya oleh dukun bayi. Selain itu ibu balita juga juga belum mengetahui cara meningkatkan nafsu makan anak dengan cara melakukan pijat tuina dan pada umumnya ibu juga merasa takut untuk memijat bayinya sendiri karena mereka belum pernah mendapatkan pelatihan tentang pijat tuina pada anak balita di Dukuh Setan, Desa Maguwoharjo, Kecamatan Depok, Kabupaten Sleman.

Berdasarkan hasil penelitian ibu dalam menjawab pertanyaan tentang pijat tuina setelah diberikan pelatihan, responden mempunyai pengetahuan yang berbeda, dimana hasil post test sesudah dilakukan pelatihan tentang pijat tuina kepada ibu meningkat menjadi cukup sebanyak 11 orang (48\%), dan baik sebanyak 5 orang (22\%). Hasil penelitian didapatkan hasil post test lebih baik dibandingkan hasil pre test, hal ini disebabkan karena adanya suatu perlakuan sebelum post tes. Responden diberikan pelatihan mengenai pijat tuina. Hal ini sesuai dengan teori Notoatmodjo (2012) menjelaskan bahwa setelah manusia mendapatkan informasi atau pelatihan maka akan diolah lebih lanjut dengan memikirkan, mengolah, mempertanyakan, menggolongkan, dan merefleksikan. Pengetahuan ibu balita yang meningkat setelah dilakukan pelatihan pijat tuina dapat direfleksikan dengan sikap yang mendukung dan mau mempraktikkan pijat tuina pada anaknya.

Faktor yang dapat mendukung efektifitas pelatihan pijat tuina pada balita bisa melalui informasi atau sumber-sumber yang digunakan misalnya pada fasilitas fisik yaitu puskesmas, dan fasilitas umum seperti televisi, radio, majalah, koran, dan internet. Fasilitasfasilitas tersebut akan mendukung sebagai merealisasikan pengetahuan dan keterampilan ibu dalam melakukan pijat pada bayi dan balita (Notoatmodjo, 2013). Meningkatnya rata-rata pengetahuan responden setelah mendapatkan pelatihan pijat tuina sejalan dengan beberapa hasil penelitian sebelumnya. Penelitian yang dilakukan oleh Ervina Rachmawati (2019) di TPA Yaa Bunayya Jember tentang efektifitas pelatihan Pijat Bayi terhadap Pengetahuan Pengasuh Bayi yang menunjukkan adanya 
peningkatan secara signifikan Nilai rata-rata responden meningkat menjadi 8,5. Hasil penelitian Erma Widhiastuti, (2012) pada dukun bayi di Wilayah Kerja Puskesmas Karangdowo Klaten, juga menunjukkan bahwa ada perbedaan signifikan skor pengetahuan responden setelah mendapatkan pelatihan pijat bayi, memperihatkan pada pre test pengetahuan semua responden memiliki pengetahuan yang kurang dan post memperlihatkan 12 responden $(92,3 \%)$ pengetahuan menjadi baik dan 1 responden $(7,7 \%)$ pengetahuan masih kurang.

Penggunaan dan pemilihan metode penyuluhan yang tepat mempengaruhi tingkat keberhasilan transfer informasi. Menurut Effendi (2002), metode yang tepat dalam memberikan penyuluhan dapat mengembangkan komunikasi dua arah antara yang memberikan penyuluhan terhadap sasaran, sehingga sasaran dapat meningkatkan pemahaman terhadap pesan yang disampaikan. Dalam penelitian ini yang diinginkan adalah perubahan pengetahuan dari responden menjadi tahu. hal ini di dukung oleh metode yang dipakai dalam memberikan pendidikan kesehatan ini menggunakan metode ceramah dan mendemonstrasikan atau mempraktikkan secara langsung langkah memijat bayi yang baik dan benar.

\section{Efektifitas Pelatihan Pijat Tuina terhadap Pengetahuan Ibu Balita}

Pada hasil penelitian ini uji hipotesis menggunakan paired sampel t test. Uji paired sampel $t$ test pada penelitian ini digunakan untuk mengetahui perbedaan pengetahuan ibu melakukan pijat tuina sebelum dan sesudah diberikan pelatihan tentang pijat tuina. Hipotesis yang menyatakan ada pengaruh pelatihan pijat tuina terhadap pengetahuan ibu dalam melakukan pijat tuina di Dukuh Setan, Desa Maguwoharjo, Kecamatan Depok dalam penelitian ini terbukti.

Ada pengaruh pelatihan pijat tuina terhadap pengetahuan ibu dalam melakukan pijat tuina sebelum dan sesudah dilakukan pelatihan pijat tuina pada ibu yang memiliki balita usia dibawah lima tahun di Dukuh Setan, Desa Maguwoharjo, Kecamatan Depok, Kabupaten Sleman. Ini dibuktikan dengan nilai signifikan <0,05. Hasil analisis menunjukkan nilai $t$ hitung lebih besar dari t tabel dan nilai $p$ signifikan lebih kecil dari 0,05.
Hal ini dapat dilihat dari hasil uji t dan nilai signifikan yang menunjukkan hipotesis diterima. Selain pembuktian secara statistik juga dapat ditinjau dari selisih rata-rata bahwa nilai rata-rata data pretest sebesar 9,39 dan rata-rata data posttest sebesar 13,7 yang memiliki selisih sebesar 4,31. Rata-rata data post test sesudah diberikan pelatihan pijat tuina lebih baik dibanding dengan rata-rata data pre test sebelum diberikan pelatihan pijat tuina. Selisih kedua data pre test dan post test bermakna.

Pendapat serupa mengenai hasil penelitian yang dilaporkan oleh Nurlaili (2018) dalam penelitiannya yang berjudul Pengaruh Pelatihan Pijat Bayi Terhadap Keterampilan Ibu Dalam Melakukan Pijat Bayi Pada Anak Usia Dibawah Satu Tahun Di Desa Lama Kecamatan Pancurbatu Menunjukkan Bahwa Adanya Pengaruh Signifikan pelatihan pijat bayi terhadap keterampilan ibu melakukan pijat bayi.

Hal ini berarti dengan adanya pelatihan pijat tuin membantu ibu dalam menambah pengetahuan ibu memijat anaknya guna meningkatkan nafsu makan anak. Pijat Tui $\mathrm{Na}$ ini merupakan tehnik pijat yang lebih spesifik untuk mengatasi kesulitan makan pada balita dengan cara memperlancar peredaran darah pada limpa dan pencernaan, melalui modifikasi dari akupunktur tanpa jarum, teknik ini menggunakan penekanan pada titik meridian tubuh atau garis aliran energi sehingga relatif lebih mudah dilakukan dibandingkan akupuntur (Sukanta, 2010). Apabila kesulitan makan teratasi maka asupan gizi bayi terpenuhi dengan baik sehingga berat badan dapat meningkat.

Pada era sekarang ini kebanyakan orang tua mengatasi kesulitan makan pada anak dengan pemberian multivitamin. Hal tersebut akan berdampak negatif jika diberikan dalam jangka waktu yang lama. Dewasa ini telah dikembangkan dari tehnik pijat bayi, yakni pijat Tui Na. Pijat ini dilakukan dengan tehnik pemijatan meluncur untuk mengatasi kesulitan makan pada balita dengan cara memperlancar peredaran darah pada limpa dan pencernaan, melalui modifikasi dari akupunktur tanpa jarum, teknik ini menggunakan penekanan pada titik meridian tubuh atau garis aliran energi sehingga relatif lebih mudah dilakukan dibandingkan akupuntur 
Hal ini sesuai hasil penelitian Yusari Asih (2018) di Wilayah Kerja Puskesmas Pagelaran Kabupaten Pringsewu dimana menunjukkan bahwa pemberian pijat tuina pada anak balita lebih efektif untuk mengatasi kesulitan makan dari pada pemberian multivitamin $(\mathrm{p}=0,000)$. Hasil penelitian lain dari Zhen Huan Liu dan $\mathrm{Li}$ ting Cen di Guangzhou tahun 2009 menyebutkan bahwa pijat Tui na berpengaruh positif terhadap perkembangan syaraf dan peredaran darah pada bayi.

\section{SIMPULAN DAN SARAN Simpulan}

Pelatihan pijat tuina pada ibu balita dapat memberikan pengaruh berupa meningkatnya pengetahuan ibu balita dalam melakukan pijat tuina untuk meningkatkan nafsu makan anak. Hal tersebut teridentifikasi melalui data yang diperoleh bahwa pengetahuan kader sebelum pelatihan (pre-test) sebanyak $97 \%$ memiliki pengetahuan kurang $3 \%$ memiliki pengetahuan cukup. Hasil yang berbeda di tunjukan setelah diberikan pelatihan (post-test) yakni ibu balita yang memiliki pengetahuan baik mengalami peningkatan menjadi lebih baik dimana terdapat 5 orang (22\%) responden yang dalam kategori baik, 11 orang $(48 \%)$ responden yang cukup dan 7 orang (30\%) responden dalam kategori kurang. Ada pengaruh pelatihan pijat tuina terhadap pengetahuan ibu dalam melakukan pijat tuina sebelum dan sesudah dilakukan pelatihan pijat bayi pada ibu yang memiliki anak usia dibawah lima tahun di Dusun Setan, Desa Maguwoharjo, Kelurahan Depok, Kabupaten Sleman. Ini dibuktikan dengan nilai signifikan $<0,05$. Hasil analisis menunjukkan nilai $t$ hitung lebih besar dari $t$ tabel dan nilai $\mathrm{p}$ signifikan lebih kecil dari 0,05. Dengan demikian, melalui penelitian ini, ibu balita di Dusun Setan, Desa Maguwoharjo, Kelurahan Depok, Kabupaten Sleman dapat mengetahui cara melakukan pijat tuina untuk meningkatkan nafsu makan anak.

\section{Saran}

Diharapkan bagi peneliti selanjutnya menggunakan meneliti tentang kemampuan praktik ibu dalam pijat tuina pada balita.

\section{DAFTAR PUSTAKA}

Adiningsih S. 2010. Waspada Gizi Balita Anda. PT. Elex Media Komputindo.Jakarta

Annif, Munjidah. 2015.Efektifitas Pijat Tui Na dalam Mengatasi Kesulitan makan Pada Balita. Jurnal Ilmiah Kesehatan ; 2015.hal 193-199.

Antolis.2012. Proporsi dan status gizi anak usia 6-24 bulan yang menglami kesulitan makan di Semarang.(studi kasus di kelurahan tandang dan sendangguwo) Jurnal media medika muda;2012

Effendi N. 2003. Dasar - Dasar Keperawatan Kesehatan Masyarakat. Edisi Kedua. EGC. Jakarta.

Ekstein S., Lanaido D., Glick B. 2010.Does Picky Eating Affect Weight-for-Length Measurments In Young Children? Clin Pediatr. 2010;49(3) : 217-220.

Erma Widhiastuti. 2012. Pengaruh Pelatihan Pijat Bayi Terhadap Pengetahuan dan Keterampilan Dukun Bayi Di Wilayah Kerja Puskesmas Karangdowo Klaten.Skripsi. Fakultas Ilmu Kesehatan Universitas Muhammadiyah Surakarta. Surakarta.

Ervina Rachmawati, Alfiansyah G, Hikmah F.2019. Efektivitas Pelatihan Pijat Bayi Terhadap Pengetahuan Pengasuh Bayi Di TPA Yaa Bunayya Jember. Jurnal Kesehatan Politeknik Negeri Jember. Vol 7 No.1. April 2019.

Kemenkes RI. 2019. Riset Kesehatan Dasar; RISKESDAS. Balitbang Kemenkes RI Jakarta.

Marimbi. 2010.Tumbuh Kembang, Status Gizi dan Imunisasi Dasar pada Balita. Nuha Medika.Yogyakarta.

Mascola, A. J., Bryson, S. W., \& Agras, W. S. 2010. Picky Eating During Childhood: A Longitudinal Study To Age 11 Years. Eating Behaviors, 11(4); 2010.hal 253257.

Notoatmodjo. 2012. Rahasia Ibu Pintar, Panduan Merawat Bayi Pasca persalinan sampai 12 Bulan. Kata Hati. Yogyakarta.

Notoatmodjo. 2013. Promosi Kesehatan dan Ilmu Perilaku. PT Rineka Cipta. Jakarta.

Nurlaili M. 2018. Pengaruh Pelatihan Pijat Bayi Terhadap Keterampilan Ibu Dalam Melakukan Pijat Bayi Pada Anak Usia 
Dibawah Satu Tahun Di Desa Lama Kecamatan Pancurbatu.Skripsi Fakultas Keperawatan Universitas Sumatra Utara. Medan.

Soedjatmoko. 2011. Masalah makan pada anak .journal of medicine. vol 10.no.1. 2011. hal 36-41.

Sukanta, P. Okta. 2010. Akupressur \& Minuman untuk Mengatasi Gangguan Kesehatan Reproduksi. PT Elex Media Komputindo.Jakarta.

Suci Rahmawati, Muharyati A, Nugraha D. 2018. Pengaruh Pemberian Terapi Akupresur Terhadap Peningkatan Nafsu Makan Pada Anak Usia 1 - 4 Tahun.Artikel Jurnal Skripsi keperawatan. Universitas Kusuma Husada Surakarta. Surakarta.

Wong F. 2011. Hipnopunktur kombinasi hipnosis + akupuntur, Penebar Plus. Jakarta

Wawan A, Dewi M. 2011.Teori Pengukuran Pengetahuan, Sikap, Dan Perilaku Manusia. MuhaMedika .Yogyakarta.

Yusari Asih, Mugiati. 2018. Pijat Tuna Efektif Dalam Mengatasi Kesulitan Makan Pada Anak Balita di Wilayah Kerja Puskesmas Pagelaran Kabupaten Pringsewu. Jurnal Keperawatan, Volume XIV, No. 1, April 2018

Zhen Huan Liu., Li-ting Cen. 2011. EffectTui $\mathrm{Na}$ On Neurodevelopment inPremature Infant.Journal ofAcupuncture and Tuina Science.Vol. 11, Issue 1, pp712.Shanghai Research Institute ofAcupuncture and Mer 